\title{
RELIGION AND THE CONSTITUTION: A RESPONSE TO LUKE BECK'S SAFEGUARD AGAINST RELIGIOUS INTOLERANCE THEORY OF SECTION 116
}

\author{
BENJAMIN B SAUNDERS* AND ALEX DEAGON**
}

\begin{abstract}
This article critiques Luke Beck's 'safeguard against religious intolerance' theory of section 116 of the Constitution. We argue that a plausible theory of section 116 must be able to account for the fact that, at Federation, Australia was an overwhelmingly Christian nation, which was opposed to the establishment of any religion but was not 'secular', and also for the fact that Australian society has become less religious but with many surviving remnants of the enmeshing of religion and the government. We argue that, consistent with the traditional understanding, section 116 has a federal purpose, being designed to distribute power to legislate in relation to religion throughout the Australian federation. Section 116 can also be seen as promoting religious pluralism, enabling interactions between religion and government. Beck's theory, and its separationist implications, fails to adequately take these factors into account.
\end{abstract}

\section{INTRODUCTION}

Section 116 of the Constitution provides:

The Commonwealth shall not make any law for establishing any religion, or for imposing any religious observance, or for prohibiting the free exercise of any religion, and no religious test shall be required as qualification for any office or public trust under the Commonwealth.

The traditional view is that section 116 is designed to achieve a federal purpose: by preventing the Commonwealth from legislating with respect to religion in the ways specified in that provision, power is 'reserved' to the states to legislate. 'In

* Senior Lecturer, Deakin Law School, Deakin University.

** Senior Lecturer, Faculty of Law, Queensland University of Technology. Our thanks to Joel Harrison for comments on an earlier draft.

$1 A$-G (Vic) ex rel Blackv Commonwealth (1981) 146 CLR 559, 605, 609 (Stephen J), 615-16 (Mason J), 652-3 (Wilson J) ('DOGS Case'). This traditional view has been more or less assumed in the cases and literature on section 116 without detailed articulation: see, eg, Kruger v Commonwealth (1997) 190 CLR 1, 60 (Dawson J) ('Kruger'); Nicholas Aroney et al, The Constitution of the Commonwealth of Australia: History, Principle and Interpretation (Cambridge University Press, 2015) 342; Reid Mortensen, 
1992 Stephen McLeish proposed that the interpretation of section 116 should place greater emphasis on individual rights, arguing that 'underlying s 116 there exists a general conception of state neutrality toward religion, reflected both in the avoidance of religious preferences and in respect for the autonomy of individuals in matters of religion, especially as participants in the wider community'. ${ }^{2}$ More recently, Luke Beck has proposed a 'safeguard against religious intolerance theory', which posits that section 116 is designed to prevent the Commonwealth from enacting religiously intolerant laws. ${ }^{3}$

In this article we critique Beck's theory. We argue that section 116 cannot plausibly be read as a provision which is targeted towards religious intolerance. We consider that section 116 should be seen as being informed by two principal strands. First, consistent with the traditional understanding, section 116 has a federal purpose, being intended to reserve significant areas of power to the states to legislate in relation to religion. We consider that section 116 is inescapably federal, and Beck's revisionist account does not adequately account for this. To the extent that section 116 imposes restrictions on Commonwealth legislative power, this is an expression of federalism, designed to distribute power throughout the Australian federation. Second, we argue that section 116 promotes pluralism in this federal context, which enables interactions between religion and government while rejecting the imposition of religious beliefs and practices at the Commonwealth level. Section 116 is pluralist in that it enables positive interactions between religion and the Commonwealth, for example by permitting the Commonwealth to support religion, and religion to influence the Commonwealth. In a pluralist model, the state may provide support to religion but is not identified with one particular religion or denomination. ${ }^{4}$ Beck's theory has more separationist implications and applications, as demonstrated in his work relating to section 116 and Commonwealth funding of religious individuals, organisations and programs. ${ }^{5}$

\footnotetext{
'The Unfinished Experiment: A Report on Religious Freedom in Australia' (2007) 21(1) Emory International Law Review 167, 167-77; Carolyn Evans, 'Religion as Politics Not Law: The Religion Clauses in the Australian Constitution' (2008) 36(3) Religion, State and Society 283 ('Religion as Politics Not Law'); Luke Beck, 'The Case against Improper Purpose as the Touchstone for Invalidity under Section 116 of the Australian Constitution' (2016) 44(3) Federal Law Review 505, 520-1 ('The Case against Improper Purpose'); Alex Deagon, 'Defining the Interface of Freedom and Discrimination: Exercising Religion, Democracy and Same-Sex Marriage' (2017) 20 International Trade and Business Law Review 239, 256-62 ('Defining the Interface of Freedom and Discrimination'); Alex Deagon, 'Liberal Assumptions in Section 116 Cases and Implications for Religious Freedom' (2018) 46(1) Federal Law Review 113 ('Liberal Assumptions in Section 116 Cases'); Carolyn Evans, 'Religion' in Cheryl Saunders and Adrienne Stone (eds), The Oxford Handbook of the Australian Constitution (Oxford University Press, 2018) 1033.

2 Stephen McLeish, 'Making Sense of Religion and the Constitution: A Fresh Start for Section 116' (1992) 18(2) Monash University Law Review 207, 223.

3 Luke Beck, Religious Freedom and the Australian Constitution: Origins and Future (Routledge, 2018) ('Religious Freedom and the Australian Constitution').

4 Renae Barker, State and Religion: The Australian Story (Routledge, 2019) 24-5 ('State and Religion'). As we will see, Barker also considers the federal aspects in more detail.

5 See, eg, Luke Beck, 'Clear and Emphatic: The Separation of Church and State under the Australian Constitution' (2008) 27(2) University of Tasmania Law Review 161 ('Clear and Emphatic').
} 
In our view, a plausible theory of section 116 needs to be able to account for the following. First, a theory of section 116 must make sense at the time of its enactment as well as today. A theory that only accounts for the position as at Federation risks irrelevance, while a theory that is inconsistent with the history of section 116 is questionable because it risks misunderstanding why it was inserted. At Federation, Australia was an overwhelmingly Christian (and especially Protestant) nation, in which Christianity was infused widely throughout society. The distinctive Australian view of religion was opposed to the establishment of any religion but not 'secular' in a modern sense of a strict separation between religion and politics. ${ }^{6}$ As such, section 116 was intended to enable a relationship between religion and government that was not irreligious but did not establish any religion: that is, religion should be suffused throughout society but no religion should be established as the official state religion. Today, the number of religious adherents and the influence of religion in Australian society has declined, but many remnants of the enmeshing of religion and the government survive. ${ }^{7}$ Federal considerations must also be prominent in any account of section 116. Such considerations were paramount in the drafting history of section 116, and the specific prohibitions in section 116 apply only to the Commonwealth, thereby reserving power to the states to legislate in relation to religion in a manner denied to the Commonwealth.

This article is structured as follows. In Part II, we outline the three factors that a theory of section 116 must account for. In Part III, we initially outline Beck's safeguard against religious intolerance theory and its separationist implications, and indicate its considerable reliance on a historical account of the events leading to the insertion of section 116 , before identifying historical and conceptual problems with Beck's theory in Part IV. We argue that these misinterpretations of various aspects of the history consequently undermine Beck's constitutive theory. In Part V, we consider the implications of undermining Beck's theory with respect to his broad, separationist reading of section 116. In Part VI, we conclude that correcting the historical record and developing a constitutive theory of section 116 more robustly grounded in constitutional history will facilitate a well-informed consideration of the doctrinal interpretation of section 116 and the extent to which it separates religion and state.

\section{WHAT A THEORY OF SECTION 116 MUST ACCOUNT FOR}

In this Part we offer a list of things that a theory of section 116 must be able to account for, which draws from key aspects of the distinctive Australian relationship between religion and the state, and key aspects of the Federal Convention debates.

6 For an overview of the different nuances of 'secular', see Alex Deagon, 'Secularism as a Religion: Questioning the Future of the "Secular" State' (2017) 8 Western Australian Jurist 31 ('Secularism as a Religion').

7 Stephen A Chavura, John Gascoigne and Ian Tregenza, Reason, Religion, and the Australian Polity: A Secular State? (Routledge, 2019) 10. For example, the Commonwealth continues to financially support religious schools, and Parliament still opens with the Lord's Prayer. 


\section{A The Australian Religious Settlement}

First, it is important to understand the historical and theological background to the drafting of section 116. In a recent article, we undertook a detailed examination of this context; ${ }^{8}$ in this section we summarise key aspects of that context. The majority view as at Federation was that Australian society was built on a Christian basis, and that there should be no established religion. As at Federation, Australian society was overwhelmingly Christian: in 1901, Christians made up $96.1 \%$ of the population (approximately $73.4 \%$ Protestant and $22.7 \%$ Roman Catholic), with those adhering to other religions or no religion amounting to less than $2 \%{ }^{9}$ The Federation period represented the peak of Protestant influence in Australia. ${ }^{10}$ It is unsurprising that there was a widespread belief in the importance of religion, and a belief that religion provided the basis for morality and underlay much of society's shared values. Patrick McMahon Glynn voiced a common belief at the Convention debates when he said that 'religion is the basis of civil society'. "This explains why many believed that God should be publicly recognised in the Constitution.

Section 116 is sometimes appealed to in order to support an argument that Australia is a secular nation, although commentators have conflicting views on what 'secular' means, and some scholars advocate a separationist reading of section 116. ${ }^{12}$ Some features of Australia's history may appear to support a secular or separationist understanding of section 116. State funding for religious schools was removed by all the Australian colonies by Federation, ${ }^{13}$ and in the late $19^{\text {th }}$ century there was also a belief in the separation of church and state, namely that the institutions of church and state should be kept separate..$^{14}$ Another key principle was that of non-establishment, namely that no religion or denomination should be established as the official religion of the state, which was directly included in

8 Alex Deagon and Benjamin B Saunders, 'Principles, Pragmatism and Power: Another Look at the Historical Context of Section 116' (2020) 43(3) Melbourne University Law Review 1033.

9 Australian Bureau of Statistics, Year Book Australia, 2006 (Catalogue No 1301.0, 20 January 2006) Table $12.26<$ https://www.abs.gov.au/ausstats/abs@.nsf/bb8db737e2af84b8ca2571780015701e/ bfdda1ca506d6cfaca2570de0014496e!OpenDocument>. The figure of $73.4 \%$ has been arrived at by adding the figures for Anglicans (39.7\%) and Other Christians (33.7\%), which may include religious adherents such as Orthodox adherents who are not Protestant.

10 Stuart Piggin, Spirit of a Nation: The Story of Australia's Christian Heritage (Strand Publishing, $2^{\text {nd }}$ ed, 2004) 49.

11 Official Report of the National Australasian Convention Debates, Adelaide, 22 April 1897, 1185 (Patrick Glynn).

12 Barker, State and Religion (n 4) 41-2; Deagon, 'Secularism as a Religion' (n 6) 53-60. Examples include Reid Mortensen, 'Blasphemy in a Secular State: A Pardonable Sin?' (1994) 17(2) University of New South Wales Law Journal 409, 426-7 (section 116 is 'one of our most important institutions of liberal secularism'); Hoxton Park Residents Action Group Inc v Liverpool Council (2016) 310 FLR 193, [249] (Basten JA) (section 116 'establishes the Commonwealth as a secular polity'); Margaret Thornton and Trish Luker, 'The Spectral Ground: Religious Belief Discrimination' (2009) 9 Macquarie Law Journal 71, 72 (Australia is committed to 'the philosophy of state secularism'); Beck, 'Clear and Emphatic' (n 5) $182,187,195$ ('Australia's system of government is secular', Australia is a 'secular state' with 'secular institutions of government'); Wojciech Sadurski, 'Neutrality of Law Towards Religion' (1990) 12(2-3) Sydney Law Review 420.

13 Renae Barker, “Under Most Peculiar Circumstances": The Church Acts in the Australian Colonies as a Study of Plural Establishment' (2016) 3(3) Law and History 28, 50. Chavura, Gascoigne and Tregenza (n 7) 77-125. 
one of the clauses of section $116 .{ }^{15}$ However, a secular or separationist account of section 116 cannot be maintained. An explicit acknowledgement of the Christian God was inserted into the Constitution at the insistence of many religious leaders and church groups during the Federation Convention debates, who represented the broader wishes of the people. The institutional separation of church and state and the principle of non-establishment did not mean a belief in the removal of religion from public life. At Federation, there was a widespread belief that Australia should not be irreligious but should be underpinned by Christian values and that religion should be widely suffused throughout society. ${ }^{16}$

Aspects of this distinctive Australian approach to religion hold true today, although the dominance of Christianity has declined. Renae Barker has argued that the relationship between religion and the state today would best be described as 'pragmatic pluralism' ${ }^{17}$ Australia is a multicultural and multi-faith democracy with a large number of people professing no religion. ${ }^{18}$ Yet religion continues to play a significant role in public policy debates such as the debate in relation to the legalisation of same sex marriage. ${ }^{19}$ Australians enjoy a high level of religious freedom despite the narrow interpretation of section 116 and the lack of a charter of rights. ${ }^{20}$ There is a close relationship between the state and religion, and religion continues to play an important part in Australian life. ${ }^{21}$ Pragmatic pluralism is evident in government funding of non-government schools, including religious schools ${ }^{22}$ and tax exemptions conferred on religious organisations. ${ }^{23}$ Any theory of section 116 needs to be able to account for this.

\section{B The Federation Debates and Federalism}

Emphasising the federalist nature of section 116 has intuitive textual and contextual appeal. ${ }^{24}$ In its terms the provision only applies to the Commonwealth and does not restrict the states. It is located in Chapter V of the Constitution dealing with 'The States', which indicates that section 116 is 'part of the division of legislative power between the Commonwealth and the States' ${ }^{25}$ Section 116 is

15 Ibid.

16 See Deagon and Saunders (n 8).

17 Barker, State and Religion (n 4) 329. Barker draws on Rex Ahdar and Ian Leigh, Religious Freedom in the Liberal State (Oxford University Press, $2^{\text {nd }}$ ed, 2013) 111-12.

18 Australian Bureau of Statistics (n 9) ch 12.

19 Elenie Poulos, 'The Power of Belief: Religious Freedom in Australian Parliamentary Debates on Same-Sex Marriage' (2020) 55(1) Australian Journal of Political Science 1; Joel Anderson, Christina Georgantis and Tayla Kapelles, 'Predicting Support for Marriage Equality in Australia' (2017) 69(4) Australian Journal of Psychology 256.

20 Barker, State and Religion (n 4) 325-6; Nicholas Aroney and Benjamin B Saunders, 'Freedom of Religion' in Matthew Groves, Janina Boughey and Dan Meagher (eds), The Legal Protection of Rights in Australia (Hart Publishing, 2019) 285, 286. Barker, State and Religion (n 4) 42.

22 Stephen V Monsma and J Christopher Soper, The Challenge of Pluralism: Church and State in Five Democracies (Rowman \& Littlefield, 1997) 107-15.

23 Barker, State and Religion (n 4) 35.

24 Aroney et al (n 1) 342. See also Kruger (1997) 190 CLR 1, 60 (Dawson J).

25 Aroney et al (n 1$) 342$. 
a good example of Harrison Moore's dictum that '[i]t is a general characteristic of the Constitution that as a rule it does not impose any restraint upon government except to further some federal purpose' ${ }^{26}$

The specific prohibitions in section 116 therefore allow the states to legislate in relation to religion in a manner denied to the Commonwealth. There is extensive evidence that the framers' primary concern was a federal one, namely preventing the Constitution from denying power to the states to legislate in respect of religion, which could be considered to have been inferred by the preamble. ${ }^{27}$ This section briefly examines the Federation debates in order to unpack the reasons for proposing and accepting section 116 in the Constitution.

The draft Constitution considered by the 1897-98 Federal Convention included a clause which provided '[a] State shall not make any law prohibiting the free exercise of any religion'. ${ }^{28}$ In February 1898, Higgins proposed an amendment to this clause to (as he saw it) strengthen the protection of religious rights. Higgins's action was prompted by his anticipation that it was likely that an acknowledgement of God would be inserted into the Constitution, notwithstanding that such a proposal (moved by Patrick Glynn) had been defeated in April 1897 by a comfortable margin, largely on the grounds that it would amount to imposing the form but not the substance of religion. ${ }^{29}$ Higgins considered that it was necessary 'to re-assure a large number of good people that their rights with respect to religion will not be interfered with'.$^{30}$ Higgins was concerned that 'if there is inserted in the preamble an express recognition of the Almighty in the Constitution', this will be a 'declaration of a religious character', from which 'attempts will be made ... to pass legislation of a character which I do not think we intend to give the Federal Commonwealth power to pass'. ${ }^{31}$ The preamble could thus enable the Commonwealth to pass legislation beyond its expressly enumerated powers.

According to Higgins, in the United States of America ('US'), the religious invocations of the kind proposed in the Australian preamble had the effect that 'inferential powers are conferred upon the Congress that go beyond any dreams we have at present' ${ }^{32}$ The US decisions therefore posed a 'danger in an implied power', notwithstanding the lack of express powers to legislate on the subject of religion..$^{33}$ He concluded that "having inserted in the preamble of the Constitution certain words which, according to US precedents, would involve certain inferential powers,

26 W Harrison Moore, The Constitution of the Commonwealth of Australia (Maxwell, $2^{\text {nd }}$ ed, 1910) 331.

27 See, eg, Official Record of the Debates of the Australasian Federal Convention, Melbourne, 7-8 February 1898, 656, 658, 660, 662, 663 (Higgins), 659 (Symon), 660 (Cockburn), 660-1 (Barton), 662 (Downer); 2 March 1898, 1734, 1735, 1769, 1772 (Higgins), 1736-7 (Quick), 1738, 1770 (Barton), 1773 (Wise).

28 John M Williams, The Australian Constitution: A Documentary History (Melbourne University Press, 2005) 522.

29 Official Report of the National Australasian Convention Debates, Adelaide, 22 April 1897, 1184-9.

30 Official Record of the Debates of the Australasian Federal Convention, Melbourne, 7 February 1898, 654 (Higgins).

31 Ibid 655-6 (Higgins).

32 Official Record of the Debates of the Australasian Federal Convention, Melbourne, 2 March 1898, 1735 (Higgins).

33 Official Record of the Debates of the Australasian Federal Convention, Melbourne, 8 February 1898, 663 (Higgins). 
there is no intention on the part of the Convention to confer even inferentially these powers on the Federal Parliament' ${ }^{34}$ In short, Higgins claimed the preamble could lead to an implication which made it possible for the Commonwealth Parliament to pass religious laws, so there needed to be a provision which clearly prevented the Commonwealth from passing religious laws. ${ }^{35}$ This is the 'standard account' of Higgins' motivations for including section 116. As discussed in Part IV, Beck challenges the standard account and instead proposes that Higgins was arguing that the heads of power could be inferentially expanded by the preamble. ${ }^{36}$

However, the other framers understood Higgins to be arguing that the presence of the preamble itself could imply a power to make a religious law. This is valuable contemporaneous evidence: if they had been mistaken, Higgins could have simply corrected them. Barton understood Higgins to be arguing that the insertion of the preamble 'imported a power to make laws regarding religion', even though it is 'quite clear that the Commonwealth will have no power to make any law regarding religion, even if no amendment such as that which has been suggested is agreed to' ${ }^{37}$ Barton obviously did not think Higgins was saying the Commonwealth's enumerated powers would be inferentially expanded by the preamble. Rather, the preamble itself would '[import] a power to make laws regarding religion' despite the Commonwealth having no specific (enumerated) power to make laws regarding religion. Quick's view is also explicitly consistent with this interpretation:

I see no reason whatever for fearing that any danger will arise from placing the words in the preamble. This is a Constitution in which certain powers are conferred on the Parliament of the Commonwealth. I do not know that the placing of these words in the preamble will necessarily confer on that Parliament any power to legislate in religious matters. It will only have power to legislate within the limits of the delegated authority, and the mere recital in respect to the Deity in the preamble will not necessarily confer on the Federal Parliament power to legislate on any religious matter. ${ }^{38}$

Here, Quick distinguishes between the limited enumerated powers of the Commonwealth, and any possible conferral of a power to make religious laws. This implies Quick understood Higgins to be arguing that the mechanism to make religious laws would be implied from the preamble itself, separate from any exercise of the enumerated powers. Wise and Kingston similarly attributed the

34 Official Record of the Debates of the Australasian Federal Convention, Melbourne, 2 March 1898, 1769 (Higgins).

35 Ibid 1734, 1769 (Higgins).

36 Beck, Religious Freedom and the Australian Constitution (n 3) ch 6.

37 Official Record of the Debates of the Australasian Federal Convention, Melbourne, 8 February 1898, 661 (Barton). This needs to be read in light of Barton's belief that the heads of power would include incidental power to legislate in relation to religion: see below n 120 .

38 Official Record of the Debates of the Australasian Federal Convention, Melbourne, 2 March 1898, 1736-7 (Quick). But note Quick did misrepresent Higgins' position by claiming that recognition will 'necessarily' confer the power to make religious laws. Higgins only claimed that it may confer the power. Of course, it is nevertheless clear that Quick did not understand Higgins to be claiming that the Commonwealth would have power to pass religious laws as an inferential exercise of its enumerated powers. The recognition clause was demonstrably the catalyst: see Chavura, Gascoigne and Tregenza (n 7) 134. 
concern that the Commonwealth could make religious laws to the insertion of the preamble itself. ${ }^{39}$

Underlying Higgins's proposal were federal considerations. Higgins and the other framers wished to ensure that the Constitution did not deny power to the states to legislate in respect of religion. ${ }^{40}$ Higgins himself explicitly stated this on numerous occasions. ${ }^{41}$ In March 1898, for instance, Higgins said:

My idea is to make it clear beyond doubt that the powers which the states individually have of making such laws as they like with regard to religion shall remain undisturbed and unbroken, and to make it clear that in framing this Constitution there is no intention whatever to give to the Federal Parliament the power to interfere in these matters. My object is to leave the reserved rights to the states where they are, to leave the existing law as it is; and just as each state can make its own factory laws, or its own laws as to the hours of labour, so each state should be at full liberty to make such laws as it thinks fit in regard to Sunday or any other day of rest. ${ }^{42}$

In similar fashion, Bernhard Wise argued that 'we ought to take care to put plainly in the forefront of the Constitution the provision that the Commonwealth shall not interfere in any way with the rights of the states to regulate religious matters' ${ }^{43}$ Other framers expressed similar views. ${ }^{44}$

Two points can be made with certainty. First, Higgins' concern about the need for section 116 was due to the recognition of God in the preamble, and the inference that might be drawn about the Commonwealth's power to pass laws of a religious nature (whether that power arose from the enumerated heads of power or an implication directly drawn from the preamble). Secondly, federal considerations

39 Official Record of the Debates of the Australasian Federal Convention, Melbourne, 2 March 1898, 1774 (Wise), 1776 (Kingston).

40 See, eg, Official Record of the Debates of the Australasian Federal Convention, Melbourne, 7-8 February 1898, 656, 658, 660, 662-3 (Higgins), 659 (Symon), 660 (Cockburn), 660-1 (Barton), 662 (Downer); 2 March 1898, 1734-5, 1769, 1772 (Higgins), 1736-7 (Quick), 1738, 1770 (Barton), 1773 (Wise).

41 Official Record of the Debates of the Australasian Federal Convention, Melbourne, 7-8 February 1898, 656, 658, 660, 662, 663; 2 March 1898, 1734, 1735, 1769, 1772 (Higgins).

42 Official Record of the Debates of the Australasian Federal Convention, Melbourne, 2 March 1898, 1769 (Higgins). See also Official Record of the Debates of the Australasian Federal Convention, Melbourne, 7 February 1898, 656 (Higgins): 'I think that, whatever is done in this matter [recognising God in the preamble and inserting what would become section 116], if anything is done, ought to be done by the states. I do not think we ought to interfere with the right of the states to do anything they choose, if they think fit to do anything; but I do think that in establishing this Federal Commonwealth we ought to take care to reassure people that there will be no interference with them'. See also Official Record of the Debates of the Australasian Federal Convention, Melbourne, 2 March 1898, 1735 (Higgins): 'I will make no opposition to the insertion of seemly and suitable words [in the preamble], provided that it is made perfectly clear in the substantive part of the Constitution that we are not conferring on the Commonwealth a power to pass religious laws. I want to leave that as a reserved power to the state, as it is now. Let the states have the power. I will not interfere with the individual states in the power they have, but I want to make it clear that in inserting these religious words in the preamble of the Bill we are not by inference giving a power to impose on the Federation of Australia any religious laws'.

43 Official Record of the Debates of the Australasian Federal Convention, Melbourne, 2 March 1898, 1774 (Wise).

44 Ibid 1738 (Lyne), 1776 (Kingston). 
were of primary importance for Higgins and the other framers, who wished to ensure that the states retained power to legislate in respect of religion. ${ }^{45}$

\section{Historical and Contemporary Relevance}

A theory of section 116 must make sense at the time of its enactment as well as today. This reflects the orthodox principles of interpretation employed by the High Court. When interpreting the Constitution, the High Court frequently draws on historical evidence such as the intentions of the framers or the meaning of legal terms at the time of Federation. ${ }^{46}$ Such historical evidence is important in determining the meaning of constitutional provisions. Therefore, if an account of section 116 would be radically at odds with prevailing views at the time of Federation, then it must be considered inadequate. At the same time, the meaning of the Constitution is not restricted to its meaning as at 1900. The High Court countenances evolution in constitutional meaning, subject to overall consistency with the central meaning of a provision. ${ }^{47}$ The Constitution 'is necessarily constructed for change' ${ }^{48}$ Accordingly, a theory of section 116 must be relevant to today as well as being consistent with its historical genesis. In making this claim we are not attempting to make a normative argument about the importance of history in constitutional interpretation but simply reflecting the orthodox methodology employed by the High Court.

Given the historical facts outlined in the previous section, a plausible theory of section 116 must be able to account for the fact that, as at Federation, Australia was an overwhelmingly Christian (especially Protestant) society, in which religion was infused widely throughout society. This understanding is necessary to comprehend why section 116 was inserted and possible implications for its interpretation. Today, by contrast, Australian society is largely 'secular" ${ }^{49}$ but with many remnants of the enmeshing of religion and the state that need to be reconciled with section 116 . A plausible theory of section 116 must be able to make sense both in a Christian society, and also in today's secular society.

Accordingly, as at Federation, the distinctive Australian view of religion was anti-establishment but not 'secular' (in the modern sense). That is, it was widely held that government should not establish a particular religion, but also that religion should not be removed from society and government. ${ }^{50}$ As such, section 116 was intended to enable a relationship between Christianity and government that was not godless but did not establish Christianity. The implications of this include a belief that public expressions of religion were not considered to be inconsistent

See, eg, Official Record of the Debates of the Australasian Federal Convention, Melbourne, 7-8 February 1898, 656, 658, 660, 662, 663 (Higgins), 659 (Symon), 660 (Cockburn), 660-1 (Barton), 662 (Downer); 2 March 1898, 1734, 1735, 1769, 1772 (Higgins), 1736-7 (Quick), 1738, 1770 (Barton), 1773 (Wise). Jeffrey Goldsworthy, 'Originalism in Constitutional Interpretation' (1997) 25(1) Federal Law Review 1. See, eg, Commonwealth v Australian Capital Territory (2013) 250 CLR 441; Jeremy Kirk, 'Constitutional Interpretation and a Theory of Evolutionary Originalism' (1999) 27(3) Federal Law Review 323.

48 Chief Justice Robert French, 'Interpreting the Constitution: Words, History and Change' (2014) 40(1) Monash University Law Review 29.

49 Chavura, Gascoigne and Tregenza (n 7).

50 Deagon and Saunders (n 8). 
with section 116 and that the government could - and should - support and fund religion in various ways. As we shall argue in Part V, this implies that a strict separationist account of section 116 which some modern scholars advocate, including Beck himself, ${ }^{51}$ is not tenable.

\section{BECK'S SAFEGUARD AGAINST RELIGIOUS INTOLERANCE THEORY}

In his recent book, Luke Beck proposes a new theory of section 116, namely a 'safeguard against religious intolerance theory'. ${ }^{52}$ Beck's proposed theory is a constitutive theory which attempts to explain what kind of a provision section 116 is rather than a doctrinal interpretation of its legal operation. ${ }^{53}$ That is, his theory aims to explain the purpose or foundation of section 116, and does not purport to be a roadmap for how courts ought to interpret it. Beck adopts the definition of intolerance proposed by Melissa Williams and Jeremy Waldron, ${ }^{54}$ arguing that religious intolerance is the attempt to change, suppress, or impose penalties for holding or following (or not holding or following) religious beliefs or practices. ${ }^{55}$ Beck considers that the four clauses of section 116 are all directed to this type of religious intolerance. According to Beck, establishing a religion is intolerant 'because it frames those who are not members of the established religion as outsiders'; imposing a religious observance amounts to 'an attempt to change the religious practices of individuals'; prohibiting the free exercise of religion 'is explicitly the suppression of religious practices'; and imposing a religious test for public office "penalises individuals who do not adhere to favoured religious beliefs' by denying them access to public office. ${ }^{56}$

Beck proposes his theory in contrast to the neutrality theory proposed by Stephen McLeish in 1992. McLeish considered that 'the impulse animating s 116 is the preservation of neutrality in the federal government's relations with religion', arguing that section 116 should be seen as 'a guarantee of civil liberty', with an individual rights focus, assessing the impact of a law on individuals rather than as a limitation on federal power. ${ }^{57}$ Beck devotes the majority of his polemical energies to explaining why the neutrality theory is wrong,${ }^{58}$ but only a little over a page to explaining why the safeguard against religious intolerance theory is correct. ${ }^{59}$

Beck's argument in favour of the religious intolerance theory rests on the fact that the theory shares certain similarities with selected features of Australian constitutionalism and the drafting history of section 116 . These are as follows.

\footnotetext{
51 See, eg, Beck, 'Clear and Emphatic' (n 5).

52 Beck, Religious Freedom and the Australian Constitution (n 3$)$ ch 9.

53 Ibid 119.

54 Melissa S Williams and Jeremy Waldron, Toleration and Its Limits (New York University Press, 2008$) 20$.

55 Beck, Religious Freedom and the Australian Constitution (n 3) 119.

56 Ibid 119.

57 McLeish (n 2) 208, 210.

58 Beck, Religious Freedom and the Australian Constitution (n 3) 123-8.

59 Ibid 128-9. Note that some of the discussion at 123-4 and 127 is relevant.
} 
First, the principal objective of the 1897-98 Federal Convention was to deny power to the Commonwealth to legislate on the subject of religion; ${ }^{60}$ thus, the framers intended to prevent a vice, not imbue the Constitution with a virtue. As a result, any constitutive theory of section 116 must have a negative rather than positive direction. ${ }^{61}$ Concern that any exercise of Commonwealth legislative power might lead to religious intolerance is consistent with this focus on preventing a vice. ${ }^{62}$ Secondly, contrary to McLeish's proposed account, Beck's theory does not give conceptual primacy to rights, which is consistent with the broad contours of Australian constitutionalism. Thirdly, the intolerance theory sits comfortably with the 'non-theorised nature of Australian constitutionalism and its lack of concern with philosophical questions about the nature of the state'. ${ }^{63}$ Thus, Beck argues that a constitutive theory of the foundations of section 116 needs to 'have a negative direction and be conceptually modest in terms of its substantive content', and his intolerance theory has those characteristics. ${ }^{64} \mathrm{~A}$ final reason for adopting the religious intolerance theory is the theme of pragmatism which lay behind the Seventh Day Adventist campaign for section 116 and which was characteristic of the approach of the framers at the Federal Convention. ${ }^{65}$

Some aspects of Beck's theory are worth noting at the outset to show what is at stake. First, his argument is framed by a particular modern understanding of intolerance, one which the framers of the Constitution and their contemporaries would not have accepted because they were generally comfortable with the public morality of an overwhelmingly Christian nation being reflected in law and public life. A second point of note is that Beck shows clear sympathy throughout his work for the position argued for by Henry Higgins and the Seventh Day Adventists, who argued for protection for religious minorities to be inserted into the Constitution. Throughout his narrative Beck questions the motives of the mainstream religious views of Protestants and Roman Catholics, arguing that they were driven principally by considerations of politics, power and expediency rather than principle. ${ }^{66}$

Thirdly, Beck's theory needs to be understood in the context of his other work. Beck has consistently advocated for a strongly separationist account of section 116, arguing for a broader interpretation of the establishment clause, ${ }^{67}$ and that section 116 prohibits parliamentary prayers, the provision of religious instruction in Territory schools, and federal funding for school chaplaincy programs and clergy ${ }^{68}$

60 Ibid 78.

61 Ibid 123-4.

62 Ibid 128. Beck does not state whose concern is relevant.

63 Ibid 128.

64 Ibid 123.

65 Ibid 128-9.

66 Ibid ch 2.

67 Luke Beck, 'The Establishment Clause of the Australian Constitution: Three Propositions and a Case Study' (2014) 35(2) Adelaide Law Review 225 ('Establishment Clause'); Luke Beck, 'Dead DOGS? Towards a Less Restrictive Interpretation of the Establishment Clause: Hoxton Park Residents Action Group Inc v Liverpool City Council (No 2)' (2014) 37(2) University of Western Australia Law Review 59 ('Dead DOGS?').

68 Beck, 'Clear and Emphatic' (n 5); Beck, Religious Freedom and the Australian Constitution (n 3) 164-5. Beck has also stated that the 'JobKeeper' program as it applies to clergy would be unconstitutional 
Beck has specifically argued that section 116 'should be interpreted broadly', basing this claim on the 'general purpose of section 116' which is to provide a safeguard against religious intolerance. ${ }^{69}$ This articulation of the general purpose is in turn grounded in his reading of the history. Beck provides an example of how this works practically by considering the National School Chaplaincy Program ('NSCP'), which enables schools to obtain Commonwealth funding to provide chaplaincy services. He argues that adopting the religious intolerance theory should lead to invalidation of the NSCP under the religious test clause in section 116 by interpreting 'office under the Commonwealth' more broadly, contrary to the outcome in Williams $v$ Commonwealth ('Williams [No 1]'). ${ }^{70}$

In relation to the establishment clause, Beck challenges the reasoning in Attorney-General (Vic) ex rel Black v Commonwealth ('DOGS Case') and contends that while 'establishing any religion' has the core meaning articulated in the DOGS Case, this does not exhaust that meaning, and the establishment clause may apply to prohibit a broader range of programs such as the NSCP. ${ }^{71}$ Beck argues for a broader interpretation of establishment which considers the practical effect of a law, not its purpose. ${ }^{72} \mathrm{He}$ argues that the establishment clause "prohibits federal expenditure for religious purposes such as religious activities' and also that 'a relationship or association between state and religion ... amounts to an identification of the state with a religion' ${ }^{73}$ Further, the establishment clause prohibits the Commonwealth establishing programs which result in a religion being identified with the states or territories. ${ }^{74}$ This expanded definition encompasses the NSCP, which renders it constitutionally 'in doubt'. ${ }^{75}$

Therefore, according to Beck, the safeguard against religious intolerance theory is the most accurate explanation of the historical and conceptual constitutional context of section 116. This constitutive theory has the practical effect of significantly expanding the reach of section 116, particularly the establishment clause, with the result that it would have the separationist outcome of invalidating a number of Commonwealth practices, interactions and programs which involve religion. ${ }^{76}$

because it establishes a religion: Nick Bonyhady, 'Experts Split over Constitutionality of JobKeeper for Priests, Imams, Rabbis', The Sydney Morning Herald (online, 2 July 2020) <https://www.smh.com.au/ politics/federal/experts-split-over-constitutionality-of-jobkeeper-for-priests-imams-rabbis-20200702p558e3.html>.

69 Beck, Religious Freedom and the Australian Constitution (n 3) 161-3.

70 Ibid 164-5, citing (2012) 248 CLR 156 ('Williams [No 1]'). See Alex Deagon, 'Book Forum on Luke Beck's Religious Freedom and the Australian Constitution', AUSPUBLAW (Blog Post, 21 November $2018)<$ https://auspublaw.org/2018/11/book-forum-alex-deagon/>.

71 Beck, 'Dead DOGS?' (n 67) 66-8; Beck, 'Establishment Clause' (n 67) 227-30. Beck also argues for a broader interpretation of the establishment clause because the strict 'for the purpose of' approach is unsound and inconsistent with more recent High Court authority in Beck, 'The Case against Improper Purpose' (n 1) 521-3.

72 Beck, Religious Freedom and the Australian Constitution (n 3) 162-3.

73 Beck, 'Establishment Clause' (n 67) 226, 240.

74 Deagon, 'Liberal Assumptions in Section 116 Cases' (n 1) 132; Beck, 'Dead DOGS?' (n 67) 70-1; Beck, 'Establishment Clause' (n 67) 234-5, 240.

75 Beck, 'Establishment Clause' (n 67) 250.

76 Beck, Religious Freedom and the Australian Constitution (n 3) 158. 
In response, we argue that Beck's constitutive theory is not an accurate explanation of the historical and conceptual context of section 116, for the reasons outlined in Part IV. This suggests that the separationist positions advocated for by Beck are not consistent with the constitutive nature of section 116.

\section{PROBLEMS WITH BECK'S THEORY}

In this Part we identify various weaknesses with Beck's theory, including conceptual problems with his argument and especially the fact that he has misread crucial aspects of the historical context.

\section{A Conceptual Problems}

\section{Inconsistency with the Preamble}

Beck's theory has the absurd consequence that the Constitution itself is intolerant. Beck argues that establishing a religion is intolerant 'because it frames those who are not members of the established religion as outsiders' ${ }^{77}$ However, on Beck's own account, the acknowledgement of God in the preamble to the Australian Constitution does precisely this. Beck approvingly quotes Andrew Inglis Clark to the effect that the constitutional recognition of God amounts to the imposition of a 'confession or declaration of religious doctrine or belief upon a minority of the same nation or community' ${ }^{78}$ According to this logic, the preamble itself is intolerant, and, according to Beck's account, is the type of mischief to which section 116 is directed.

A better approach would be to read the Constitution in a manner that leads to consistency rather than inconsistency between its provisions and the preamble, and to read section 116 so as to best make sense of the Constitution as a whole. ${ }^{79}$ While the framers may have introduced section 116 in its present form into the Constitution pragmatically, ${ }^{80}$ it would be difficult to argue that they did so with no regard for its interaction with the preamble, given that the introduction of section 116 into the Constitution was expressly provoked by the decision to recognise God in the preamble. ${ }^{81}$ Further, as we discuss below, a more accurate understanding of the historical context reveals that the preamble was amended to recognise God based on principled theological convictions about the role of religion in society rather than mere pragmatism. ${ }^{82}$ This makes the idea that section 116 is designed to prevent intolerance in the manner defined by Beck a difficult one to accept.

\footnotetext{
77 Ibid 119.

78 Ibid $15-17$

79 This follows the recent tendency of the High Court to view the Constitution as a coherent and integral document, exemplified in cases such as Wurridjal v Commonwealth (2009) 237 CLR 309.

80 Beck, Religious Freedom and the Australian Constitution (n 3) 120-1.

81 Ibid ch 6 .

82 Deagon and Saunders (n 8).
} 


\section{Subjectivity and False Equivalence}

As we saw above, Beck argued for the safeguard against religious intolerance theory on the basis that, unlike McLeish's neutrality theory, the intolerance theory does not give conceptual primacy to rights, is consistent with the Convention's aim to deny the Commonwealth power to legislate with respect to religion, and sits comfortably with the non-theorised nature of Australian constitutionalism. ${ }^{83}$ Beck's argumentative technique is essentially to describe certain features or characteristics of Australian constitutionalism and the drafting history of the Constitution, and then propound a theory that shares those characteristics.

There are three major weaknesses with this approach. The first is that the characteristics relied on by Beck are subjective in their selection and evaluation. Beck selects a number of characteristics of Australian constitutionalism which mandate the rejection of the neutrality theory and acceptance of the intolerance theory. But, as we discussed above in Part II, there are other characteristics which we consider are more important, and which Beck's theory does not account for. Beck's characteristics are also subjective in their evaluation. Beck argues that any account of section 116 must be 'conceptually modest' and critiques McLeish's account on the basis that it is not 'substantively minimalist' because it draws from American jurisprudence ${ }^{84}$ However, this seems a subjective evaluation and Beck's theory seems no more or less 'conceptually modest' than McLeish's version.

The second weakness is that Beck's characteristics are described at a high level of abstraction. Beck argues that any constitutive theory of section 116 must have a 'negative direction' because the framers intended to prevent a vice, not imbue with a virtue.$^{85}$ While this may be true, stated in this abstract way the proposition is not particularly enlightening. Not every theory which has a 'negative direction' will amount to a plausible account of section 116. The framers did not intend to prevent any type of vice, but a particular vice, namely preventing the Commonwealth from legislating in relation to religion. ${ }^{86}$ There is no indication that the framers intended to prevent religiously intolerant laws in the sense proposed by Beck.

Thirdly, Beck's arguments display the fallacy of false equivalence. The mere fact that Beck's theory shares certain characteristics in common with Australian constitutionalism does not mean that his theory is the best account of section 116 . Other theories of section 116 may equally have a 'negative direction', not give conceptual primacy to rights, and be pragmatic. Indeed, the traditional view of section 116 shares all these characteristics, which illustrates the lack of grounds for Beck to prefer his account over others. 


\section{B Historical Problems}

\section{Failure to Understand the Historical Context}

Beck's reading of the history plays a crucial role in the articulation and defence of his proposed safeguard against religious intolerance theory, with almost every reason articulated by Beck having reference in some way to the historical context of section 116. The neutrality theory proposed by McLeish is, Beck argues, 'not supported by and [is] inconsistent with key features of the origins of section $116^{9} .^{87}$ Beck considers that key elements of the history include the nature of the campaign for constitutional recognition by colonial church leaders, the drafting history of section 116 including Higgins's argument for its inclusion, the nature of Australian constitutionalism, and an overall approach of pragmatism. ${ }^{88}$ However, we recently argued in detail that Beck has misread crucial aspects of the historical context, including by misunderstanding mainstream views regarding religion and the state at the time of Federation, and also the distinctive Australian settlement regarding religion and the state ${ }^{89}$ By the Federation period, the Australian view of religion and the state was non-establishment but also non-secular, namely 'that the state should not be godless, and yet that it should not privilege one Christian church over others' ${ }^{90}$ This is a crucial feature of the historical context that any adequate theory of section 116 must be able to account for, which significantly weakens Beck's proposed safeguard against religious intolerance theory. Also, Beck fails to account adequately for the focus on state rights in the Convention Debates. ${ }^{91}$ This was by far the overwhelming concern of the framers at the Federation Conventions, but receives little attention in Beck's theory. ${ }^{92}$

Beck claims that the overall approach of Protestant religious leaders was pragmatic, and particularly that the campaign for constitutional recognition of God by the churches was concerned with pragmatist politics and power and argues that this theme of pragmatism is an important reason for accepting the intolerance theory. ${ }^{93}$ While it is true that there were elements of pragmatism in debates

\section{Ibid 123.}

88 Ibid $123-9$.

89 Deagon and Saunders ( $\mathrm{n}$ 8).

90 Chavura, Gascoigne and Tregenza (n 7) 126.

91 Some brief considerations are contained in, for example, Beck, Religious Freedom and the Australian Constitution (n 3) 53-4, but these are part of historical narratives rather than principled expositions. Other scholarship on section 116 either does not discuss the federalist aspect in detail or focuses purely on doctrinal operation: see, eg, Joshua Puls, 'The Wall of Separation: Section 116, the First Amendment and Constitutional Religious Guarantees' (1998) 26(1) Federal Law Review 139; Evans, 'Religion as Politics Not Law' (n 1); Reid Mortensen, 'The Establishment Clause: A Search for Meaning' (2014) 33(1) University of Queensland Law Journal 109; Beck, 'The Case against Improper Purpose' (n 1); Deagon, 'Defining the Interface of Freedom and Discrimination' (n 1); Paul Babie, 'National Security and the Free Exercise Guarantee of Section 116: Time for a Judicial Interpretive Update' (2017) 45(3) Federal Law Review 351; Deagon, 'Liberal Assumptions in Section 116 Cases' (n 1). Barker does consider the federalist issues in some detail: Barker, State and Religion (n 4) 82-4, 95-8.

92 Beck does consider the federal motivations of the framers when discussing how section 116 came to be drafted into the Constitution (see Beck, Religious Freedom and the Australian Constitution (n 3) chs 5-6) but it figures little in his theory of section 116 (see Beck, Religious Freedom and the Australian Constitution (n 3) ch 9).

93 Beck, Religious Freedom and the Australian Constitution (n 3) 123-9. 
regarding section 116, the overall approach of the church leaders in regard to recognition was far more principled, based in deep theological convictions about the role of religion in public life. ${ }^{94}$ Similarly, many members of the Convention provided strongly principled reasons for affirming or rejecting the recognition of God and the insertion of section 116. These were primarily federalist concerns associated with power that the Commonwealth may have to interfere with religion, and the maintenance of state rights in this context. We have already considered some aspects of this above. ${ }^{95}$

Renae Barker has recently provided a detailed history of section 116 which both accords with the standard account, and emphasises the importance of federal considerations for the debate. ${ }^{96}$ Higgins, along with other secularists and the Seventh Day Adventists, was concerned that if Australia could be seen as a Christian nation due to recognition of God in the preamble, this might empower the Commonwealth to enact Sunday observance laws. ${ }^{97}$ The prevailing view at the Convention was that legislating in relation to religion should be left to the states. This was desirable so that, amongst other reasons, the states could prohibit religious practices that were considered to be incompatible with civil society such as murder or sacrifice, selfmutilation, or even faith healing without conventional medical treatment. ${ }^{98}$ Higgins and his supporters were perfectly willing to allow Sunday observance laws as long as the states imposed it rather than the Commonwealth, which suggests that the delegates were much more concerned with preserving state rights than preventing the imposition of religiously intolerant laws. ${ }^{99}$ Fundamentally, the introduction of section 116 into the Constitution was not driven by concern for freedom of religion in the abstract. ${ }^{100}$

Thus, federalism was central to the historical context of section 116 . Including section 116 was (at least) just as much about reserving powers on religion to the states as it was about religion itself. ${ }^{101}$ Barker even goes as far as to say section

\section{See Deagon and Saunders (n 8).}

95 It is possible that some of the historical record supports the view that the framers had originally intended that section 116 would serve as a prohibition against both the Commonwealth and the states, which would seem to undermine its federalist purpose. However, this record mainly consists of the original proposal by Andrew Inglis Clark at the 1891 Convention, which was essentially transposed by Higgins for introduction at the 1897-98 Conventions. It then became clear that there was little support for limiting state powers, so the clause was amended and eventually accepted in its current federalist form. See Beck, Religious Freedom and the Constitution (n 3) 86-91.

96 Barker, State and Religion (n 4) 68-100. This account is also supported by Chavura, Gascoigne and Tregenza (n 7) 130-4.

97 Barker, State and Religion (n 4) 77.

98 Ibid $80-1$.

99 Ibid.

100 Ibid 85.

101 Ibid 83. This also contradicts McLeish (n 2) 208-12, who argues that the High Court's focus on federalism in doctrinal interpretation has led to an inappropriate textualist approach, but the availability of extrinsic aids and reference to the debates enables a broader 'neutrality' approach to section 116. While we do not specifically engage with McLeish's theory or the issue of doctrinal interpretation here, it is worth noting that reference to the history, in our view, rather leads to (or at least is consistent with) an approach which could accord with the general federalist focus of the High Court, while also facilitating a broader framework for interpretation than mere textual analysis. 
116 was primarily about state rights rather than freedom of religion..$^{102}$ Chavura, Gascoigne and Tregenza also note that a major concern was the freedom of the states to retain 'the right to do what they think is necessary to preserve and maintain their civilisation', including to legislate with respect to religion. ${ }^{103}$ Thus, it was not considered appropriate to enable the Commonwealth to prevent, for example, the states from passing laws regarding Sunday trading. ${ }^{104}$

At Federation there was never any formal or absolute separation of church and state, and the colonial governments could have chosen to establish a church or prohibit the free exercise of any religion at any point. ${ }^{105}$ Section 116 did not change this, which suggests it was not intended to fetter the power of the states to legislate with respect to religion, nor to prevent religiously intolerant laws as a matter of principle, nor to institute a complete, formal, secularist separation of church and state. Instead, the colonies, and later the states, chose a de facto separation which amounted to non-establishment and religious freedom but did not amount to the strict secularism articulated by the likes of Barton. ${ }^{106}$ As a result of facilitating state autonomy with respect to religion there is significant, legitimate interaction between religion and government in such important policy areas as education and welfare which reside within state plenary powers. ${ }^{107}$ As already mentioned, even Higgins and his supporters 'were prepared to allow Sunday observance laws as long as it was the States and not the Commonwealth who legislated for it'. ${ }^{108}$

Beck argues that section 116 is directed at preventing religious intolerance. However, section 116 simply denies power to the Commonwealth to enact certain laws, thereby reserving full power to enact such laws to the states, including religiously intolerant laws. ${ }^{109}$ We argue below that the framers were not concerned about intolerance as Beck conceives it. Thus, it is unlikely that section 116 can be convincingly read as an attempt to defeat religious intolerance. In short, if section 116 was intended to safeguard against religious intolerance, as indicated by the historical context, we would expect the historical context to reflect a view that section 116 should apply to the states as well as the Commonwealth as a matter of principle given that states can be religiously intolerant as much as the Commonwealth. Instead, the framers very clearly emphasised the need for states to maintain their powers with respect to religion.

Thus, a more plausible explanation is that section 116 is best read - as Beck himself acknowledges was the intention of the framers - as having been inserted 'chiefly as a pragmatic matter to ensure that the Commonwealth would have no power on the subject of religion', ${ }^{110}$ thereby reserving such power to the states. It is important to stress the federal dimensions of section 116, because a theory that

102 Barker, State and Religion (n 4) 84.

103 Chavura, Gascoigne and Tregenza (n 7) 131, quoting Samuel Cockburn.

104 Ibid; Barker, State and Religion (n 4) 77-8.

105 Barker, State and Religion (n 4) 96-8.

106 Ibid 97-8.

107 Ibid 98.

108 Ibid 84.

109 See the discussion in Aroney et al (n 1) 341-2.

110 Beck, Religious Freedom and the Australian Constitution (n 3) 120. 
ignores or downplays these dimensions ${ }^{111}$ misses arguably the core purpose of section 116. In particular, the limitations in section 116 apply only to the Commonwealth. However unlikely politically, there is nothing in the Constitution which limits the power of a state government from enacting legislation which establishes a religion, or imposes a religious observance, or prohibits the free exercise of religion, and the states would have full legal power to impose a religious test as a qualification for any state office or public trust. The Constitution is only concerned about these things insofar as they are imposed or enacted by the Commonwealth.

\section{Higgins' Argument for the Inclusion of Section 116}

Beck has undertaken a detailed revisionist account of the incorporation of section 116 into the Constitution. As alluded to previously, the 'standard narrative' of Higgins' argument for section 116 is as follows. Notwithstanding the absence of an express power to legislate with respect to religion, the insertion of the words 'humbly relying on the blessing of Almighty God' in the preamble to the Constitution could give rise to an implication that the Commonwealth was empowered to legislate with respect to religion. A provision such as section 116 was therefore considered necessary to prevent any such implication being drawn or to counteract any such implication. ${ }^{112}$ Beck considers that this account is incorrect. He argues instead that Higgins' concern was that the preamble may broaden the scope of the heads of legislative power in the Constitution to include the ability to make religious laws, rather than that the preamble itself may give rise to an implication that the Commonwealth has the ability to make religious laws. Beck supports this argument by reference to Higgins' reference to US jurisprudence (supplemented by reliance on a constitutional text whose identity is not known for certain) which held that the US was a Christian nation, and so Congress could enact a Sunday observance law through an inferential exercise of its enumerated powers. According to Higgins, "[i]f that was possible in America, it might also be possible in Australia' if Australia had a preamble which recognised God. ${ }^{113}$ Beck considers that this supports his intolerance theory. ${ }^{114}$

However, there are weaknesses with this argument. First, Beck's account is a convoluted interpretation of the Convention Debates. During the 1898 Convention, Barton noted that in the Church of the Holy Trinity case, ${ }^{115}$ the Supreme Court held that the US was a Christian nation. Although that aspect of the ruling was obiter dictum, he noted that the decision was later acted upon, as pointed out 'in a little handbook' which Higgins lent to Barton. Beck attempts to ascertain the identity of this book, concluding that the evidence is 'inconclusive and a confident identification ... is therefore not possible'. ${ }^{116}$ Nevertheless, from Barton's rather cryptic reference in passing to a 'little handbook', Beck suggests a fundamentally

111 As Beck's account does: ibid ch 9.

112 Beck, Religious Freedom and the Australian Constitution (n 3) 59.

113 Ibid 71-3.

114 Ibid 76-7, 119.

115 See Church of the Holy Trinity v United States, 143 US 457 (1892).

116 Beck, Religious Freedom and the Australian Constitution (n 3) 71. 
different interpretation of Higgins' reasoning for the inclusion of section 116 . Beck's contentions therefore rely on speculation as to how Higgins may have interpreted what was contained in a book that Beck may or may not have correctly identified. Beck's assertions that the standard account is 'far from a complete or accurate account' and that it 'does not withstand detailed scrutiny' ${ }^{117}$ therefore appear to be a significant overstatement.

Beck also asserts that Higgins' argument for section 116 is one that he struggled to articulate coherently. ${ }^{118}$ However, this only applies to Beck's revisionist account of section 116. The standard account presents no such difficulty. In fact, as we explained above in Part II, Higgins' arguments were quite clear, well articulated, and were clearly understood by his hearers. The standard account has the virtue of simplicity and is the most straightforward interpretation of the debates. It is unlikely that Higgins meant something different from what is conveyed by his clearly expressed statements, and from what his hearers took him to be arguing. As we argued in more detail in Part II of this article, there is abundant evidence for the standard account in the Convention Debates.

The most telling argument against Beck's account, however, is that some framers expressly recognised that the enumerated powers of the Commonwealth may include power to legislate with respect to religious matters, which they saw as a good thing. This indicates that the concern was not with preventing religious intolerance by denying the Commonwealth any power to make laws respecting religion, but with ensuring the preamble would not confer additional power upon the Commonwealth. Barton referred to the possibility that adherents of other religions might enter the Commonwealth holding to various practices which would be 'totally abhorrent' to the ideas of any civilised community. ${ }^{119} \mathrm{He}$ envisaged that the Commonwealth power relating to 'immigration and emigration, and with regard to naturalization, and also with regard to the making of special laws for any race' would enable the Commonwealth to pass laws preventing practices 'which are abhorrent to the ideas of humanity and justice of the community'. ${ }^{120}$ Indeed, he was concerned that section 116 would deprive the Commonwealth of this power. ${ }^{121}$ Thus, although the Commonwealth did not have a freestanding right to legislate in relation to religion, the heads of legislative power would be broad enough to encompass some power to regulate religious matters. Far from being concerned that the heads of legislative power would enable the Commonwealth to make laws relating to religion, the framers thought this to be necessary and desirable.

In any case, were Beck's revised account to be accurate, it does not make a great deal of difference, nor is it clear how Beck's account is a reason for rejecting the neutrality theory in favour of Beck's intolerance theory. ${ }^{122}$ That is, even if it

117 Ibid 61, 126.

$118 \operatorname{Ibid} 73,75$.

119 Official Record of the Debates of the Australasian Federal Convention, Melbourne, 2 March 1898, 1771-2 (Barton).

120 Ibid.

121 Ibid.

122 Beck explains that it is not of mere historical interest because it suggests that section 116 was designed to be a partial rather than a total limitation on Commonwealth power to legislate with respect to religion. He 
is correct, it does not prove very much. Beck's account merely establishes that Higgins was concerned about the expansion of the heads of legislative power and not a freestanding implication derived from the preamble. On both accounts, federal considerations were crucial to Higgins' motivation in proposing the introduction of section 116. Beck himself acknowledges that Higgins' proposals were undergirded by federal considerations, noting that 'it was clear to all present at the Convention that Higgins was seeking to deny power to the Commonwealth to legislate in respect of religion'. ${ }^{123}$ According to Beck's own logic, federal considerations ought therefore to be at the forefront of any account of section 116, but they play little role in his intolerance theory. A federal reading is more plausible than the safeguard against intolerance theory because, as explained below, the framers were not particularly concerned about intolerance as defined by Beck.

\section{An Anachronistic Understanding of Intolerance}

The concepts of tolerance and intolerance are obviously central to Beck's safeguard against religious intolerance account of section 116. Beck adopts a definition of religious intolerance as the attempt to change, suppress, or impose penalties for holding or following religious beliefs or practices. ${ }^{124}$ We argue that Beck has applied an anachronistic and ahistorical understanding of tolerance, which reflects today's secular views, to the context surrounding the Federation debates. Australians in the late $19^{\text {th }}$ century considered that laws (such as mandatory Sunday observance laws) which gave expression to the widely held beliefs of an overwhelmingly Christian society were entirely legitimate, notwithstanding that such laws would now be considered intolerant in the largely secular, pluralist society of $21^{\text {st }}$ century Australia. A theory which proposes that section 116 should be understood as if it was intended to prohibit laws which were expressly desired by many Australians in the 1890s is unlikely to be a convincing constitutive theory of section 116. In short, the framers were not concerned about intolerance (as Beck conceives it) and so it is very unlikely that section 116 is designed to prevent intolerance.

Beck's book commences with the story of a 'sabbath breaker in the stocks', namely the arrest of bricklayer Robert Shannon in 1894 for breaching the Sunday observance laws. ${ }^{125}$ Although not expressly stated, the only possible relevance of this story to Beck's argument is that these laws provide an example of intolerance, as they amount to the imposition of religious observances upon those who held different convictions. ${ }^{126}$ But this is to read Federation history through the lens of later, $21^{\text {st }}$ century understandings of intolerance. In today's religiously diverse society, with a significant minority of those who profess 'no religion', an attempt

does not directly address why this specifically supports his theory above McLeish's, except to say that his theory is a better reflection of the history. But that is precisely what we challenge in this article. See Beck, Religious Freedom and the Australian Constitution (n 3) 76-7, 119, 126.

124 Ibid 115, 119.

125 Ibid ch 1.

126 Beck defines intolerance as 'when the state attempts to change or suppress a set of religious beliefs and practices or imposes penalties for holding or following them': ibid 119. 
to mandate Sunday observance laws could plausibly be described as intolerant. ${ }^{127}$ However, only a very small minority of the population in the 1890 s considered such laws to be intolerant. In the 1890 s, Australia was almost entirely Christian. Census figures indicated that $96.1 \%$ of the population identified as Christian with high levels of church attendance. ${ }^{128}$ Sunday observance laws reflected longstanding views about the need for a weekly day of rest and worship, based on the fourth commandment, ${ }^{129}$ and that the government was entitled to form, and express in legislation, the public conscience - even if not every single person agreed with the laws enacted. ${ }^{130}$

Further, Sunday observance laws were seen by contemporaries as a necessary protection for the worker rather than an intolerant imposition on minorities. In an era when the union movement had only recently begun to secure workers' rights, ${ }^{131}$ workers were vulnerable to exploitation and Sunday laws represented a guaranteed day of rest, not to be encroached upon by rapacious employers. ${ }^{132}$ The Seventh Day Adventists who campaigned against Sunday observance laws were a tiny minority, amounting to approximately $0.056 \%$ of the population. ${ }^{133}$ Beck himself acknowledges that 'many people' thought they had 'peculiar beliefs', including working on Sundays. ${ }^{134}$ That is, the majority of people in the 1890 s would not have been concerned about intolerance in the sense intended by Beck.

Indeed, many of the key moral issues of the 1890s, such as temperance, Sunday observance and the religion in public schools controversies were hotly contested campaigns to enshrine religious observances throughout the life of the nation. ${ }^{135}$ Many in the 1890s would have been comfortable with the types of restrictions or observances which the Adventists feared, and which would be understood as intolerant according to Beck's definition of intolerance. The recognition of God was the expression of widely held views in a Christian society. ${ }^{136}$ What the

127 See Gary Bouma, Australian Soul: Religion and Spirituality in the Twenty-First Century (Cambridge University Press, 2006) 1-2.

128 Australian Bureau of Statistics (n 9) Table 12.26.

129 The Holy Bible, Exodus 20:8, Deuteronomy 6:12-6:15. For confessional statements reflecting this, see, eg, Westminster Confession of Faith, XXXI.7-XXXI.8.

130 James Henley Thornwell, 'Relation of the State to Christ' in John B Adger (ed), The Collected Writings of James Henley Thornwell (Presbyterian Committee of Publication, 1871) 549.

131 See, eg, Greg Patmore, Australian Labour History (Longman Cheshire, 1991) ch 4; RS Hamilton (ed), Waltzing Matilda and the Sunshine Harvester Factory: The Early History of the Arbitration Court, the Australian Minimum Wage, Working Hours and Paid Leave (Fair Work Australia, 2011).

132 Pope Leo XIII, 'Rerum Novarum: Encyclical of Pope Leo XIII on Capital and Labor' in Jordan J Ballor (ed), Makers of Modern Christian Social Thought: Leo XIII and Abraham Kuyper on the Social Question (Acton Institute, 2016) 5, 27 [41]-[42]; 'Report of Public Questions Committee', in Presbyterian Church of Victoria, Proceedings of the General Assembly (Melbourne, November 1898) lxxix. Many thanks to the Presbyterian Church of Victoria archivist, Mrs Chris Palmer, for providing access to the archives. Sabbatarianism was also well accepted in England and America at the time: see, eg, SJD Green, The Passing of Protestant England: Secularisation and Social Change (Cambridge University Press, 2011).

133 As deduced from Beck, Religious Freedom and the Australian Constitution (n 3) 20.

134 Ibid.

135 See, eg, JS Gregory, Church and State: Changing Government Policies towards Religion in Australia (Cassell Australia, 1973).

136 See, eg, 'Public Questions Committee Report' in Presbyterian Church of Victoria, Proceedings of the Commission of the General Assembly (Melbourne, May 1897) 19, x. 
Adventists considered to be an imposition upon conscience would not have been considered to be so by many mainstream views. Contemporaries were comfortable in principle with religiously intolerant laws (as Beck defines intolerance). Thus, Beck's intolerance theory is a highly anachronistic approach which reads Federation history through the lens of a minority position. If history is to inform an account of section 116, any coherent account would indicate that section 116 cannot be directed to preventing something which the overwhelming majority of society would have considered desirable at the time of its enactment. The widespread acceptance of observances and practices, which would be considered to be intolerant as Beck defines it, undermines the plausibility of Beck's safeguard against religious intolerance theory. ${ }^{137}$

\section{IMPLICATIONS: PLURALISM AND SEPARATIONISM IN SECTION 116}

We have argued that the religious intolerance theory is incomplete, contains conceptual mistakes, and is based on a highly questionable reading of the historical context. This Part outlines the implications for understanding section 116.

Beck's overall view of section 116 is a strongly separationist one, namely that it encapsulates a position of secularity in Australia's system of government, that there ought to be limited public recognition of religion and that governments ought to have limited involvement with religion. He describes section 116 as 'a provision separating religion and government ${ }^{138}$ and 'the separation of religion and government provision of the Australian Constitution'; ${ }^{139}$ he also writes that section 116 'appears to be a secular separation of religion and state constitutional provision'. ${ }^{140}$ In an earlier article Beck argued that the practice of parliamentary prayers 'contradicts the received wisdom that Australia's system of government is secular and religiously neutral'. ${ }^{141} \mathrm{He}$ argues that section 116 should not be interpreted narrowly, and, as noted above, he argues for a broader interpretation of the establishment clause, which would result in further limiting the power of the Commonwealth in relation to religion..$^{142}$

Beck's argument in relation to the establishment clause illustrates a key weakness in his theory. He argues that the clauses of section 116 are examples of intolerance, and that establishing a religion is intolerant 'because it frames those who are not members of the established religion as outsiders' ${ }^{143}$ He also argues that establishment is not simply about setting up a national church, but 'something

137 Cf Beck, Religious Freedom and the Australian Constitution (n 3) 128-9.

138 Ibid 12. Beck refers to this as 'putting religion in the Constitution'.

139 Ibid 4.

140 Luke Beck, 'The Theological Underpinnings of Australia's Constitutional Separation of Church and State Provision' (2018) 64(1) Australian Journal of Politics and History 1, 16.

141 Beck, 'Clear and Emphatic' (n 5) 195.

142 Beck, Religious Freedom and the Australian Constitution (n 3) 161; Beck, 'Establishment Clause' (n 67); Beck, 'Dead DOGS?' (n 67).

143 Beck, Religious Freedom and the Australian Constitution (n 3) 119. 
broader about giving official imprimatur to religions and religious principles'. ${ }^{144}$ However, these two arguments do not sit well together. It is true that establishing a religion as the official religion of a country is likely to convey the impression to non-adherents of that religion that they are outsiders. But government support for religious activities does not do this. For example, it is difficult to see how funding a national chaplaincy program is intolerant, given that it does not attempt to change or suppress religious beliefs and practices or impose penalties for holding or following them. ${ }^{145}$

That is, the broader the interpretation of the establishment clause, the less the activities caught by that clause look like intolerance. It is much easier to argue that the establishment clause is to do with intolerance on a narrow interpretation. And yet Beck is not willing to adopt a narrow interpretation of the establishment clause. This illustrates the weakness of his intolerance theory in accounting for the specific clauses of section 116: his account of section 116 does not sit well with his interpretation of those clauses.

Against this, we argue that a strongly separationist account of section 116 is not consistent with its drafting history or purpose, which Beck considers to be a necessary feature of a convincing account of section 116. Section 116 is not designed to enshrine the separation of church and state, is not intended to separate religion from society or government and allows for positive interactions between religion and the Commonwealth. We consider that these matters are best accounted for by understanding section 116 as a pluralist provision. Renae Barker argues that religion in Australia is characterised as a 'pragmatic pluralism'. ${ }^{146}$ In a pluralist model, the state treats all religions and worldviews in an even-handed way. Rather than categorising religion as merely private, the state supports religion in all its forms in the public sphere. ${ }^{147}$ Barker notes that a pragmatic pluralism is pluralism adopted by a state as a pragmatic response to a pluralist society where many different religions exist. ${ }^{148}$ Barker contends that for largely pragmatic reasons Australia provides funding to religious schools and tax exemptions to religious organisations, which is consistent with pragmatic pluralism. ${ }^{149}$

One of the primary concerns facing Australia in the late 1890s was ensuring that religious difference did not devolve into religious conflict. The claim that Australia was a secular state is an 'illusion, brought on by an inadequate understanding of what religion, and the religious condition, means, together with a dash of wishful thinking'. ${ }^{150}$ Rather, similar to the American situation, though it was felt that the community should have a religious character, the Commonwealth should avoid promoting any one religion (or denomination, as Australia at the time was almost

144 Ibid 161.

145 See further Williams [No 1$]$ (2012) 248 CLR 156, 183-4 [17] (French CJ), 285-6 [305]-[306] (Heydon J).

146 Barker, State and Religion (n 4) 25, 328-9.

147 Ibid 25.

148 Ibid. Cf Ahdar and Leigh (n 17) 111-12.

149 Barker, State and Religion (n 4) 34-5. Cf Monsma and Soper (n 22) ch 4.

150 Greg Melleuish and Stephen A Chavura, 'Utilitarianism contra Sectarianism' in William O Coleman (ed), Only in Australia: The History, Politics, and Economics of Australian Exceptionalism (Oxford University Press, 2016) 63. 
universally Christian) over any other, and avoid hindering religious liberty. It was a climate which endorsed religion and aimed to advance religion, reflected through 'the avoidance of religious preference and the protection of individual and group autonomy in matters of religion as participants in the wider community'. ${ }^{151}$

Some of the delegates to the 1898 Convention were concerned that recognition of God would allow national religious laws that could discriminate against certain religious communities, and in a 'religiously plural society where sectarian divisions were often keenly felt', this was considered to be a significant possibility. ${ }^{152}$ Section 116 was designed to prevent this discrimination through reserving power on religious matters to the states and promoting the pluralism which already existed. It was "not the result of any ardent secularist impulse seeking to banish religion from public affairs', but was accepted by the various religious communities as an appropriate mechanism to promote protection of public religion (exemplified through the religious engagement with the Federation movement itself) and protection from the federal imposition or prohibition of religious beliefs and practices. ${ }^{153}$ To this limited extent it could be said that section 116 prevents religious intolerance, but for the reasons already given the 'intolerance' theory is historically and conceptually problematic, and consequently does not lead to viewing section 116 as a separationist provision or provide a complete picture of why section 116 exists.

Section 116 limits Commonwealth power on specified matters with respect to religion. It does not in its terms or effect impose a strict separation of religion and government. Nothing in section 116 prohibits or prevents the Commonwealth (or the states) from positively fostering diverse religious beliefs in a non-discriminatory way. The provision has not 'prevented a significant amount of interaction from taking place between the State and religion at both a federal and state level' ${ }^{154}$

The widely held views, at Federation, about the legitimate and positive influence of religion, and the impact of religious views on the formation of the Constitution, are important historical facts relevant to the foundation of section 116. Section 116 was never intended to achieve a true, strict separation of religion and politics. ${ }^{155}$ Beck's positions that section 116 prohibits parliamentary prayers, the provision of religious instruction and funding for religious programs are not consistent with a historical or conceptual understanding of the provision. Rather, section 116 enables positive interactions between religion and the Commonwealth by permitting the Commonwealth to support religion and permitting religion to influence the Commonwealth.

This provides a more satisfactory basis for understanding the four clauses of section 116. It suggests that the current narrow interpretation of the establishment clause ${ }^{156}$ is consistent rather than inconsistent with the nature and purpose of section

151 Deagon, 'Secularism as a Religion' (n 6) 58. See also Chavura, Gascoigne and Tregenza (n 7) 126; McLeish (n 2) 221-3; Puls (n 91) 140.

152 Chavura, Gascoigne and Tregenza (n 7) 137. Religiously plural in the sense of different Christian denominations rather than entirely different religions.

153 Ibid.

154 Barker, State and Religion (n 4) 99.

155 See Deagon and Saunders (n 8). See also above n 12.

156 DOGS Case (1981) 146 CLR 559. 
116. ${ }^{157}$ Properly understood in its historical context, section 116 is not opposed to 'giving official imprimatur to religions and religious principles', ${ }^{158}$ but only with preventing a religion from being established as the officially endorsed national (or state) religion. This is evident from the distinctive Australian view of government and religion, as noted earlier.

Further, the pragmatic pluralist understanding better accounts for the religious test clause of section 116. Beck claims that the NSCP breaches the religious test clause, arguing that had the reasoning in Williams [No 1] 'been structured and disciplined by the idea that section 116 should be interpreted to avoid religious intolerance on the part of the Commonwealth' then the outcome would have been different. ${ }^{159}$ However, Beck does not explain why this is the case, but merely asserts it. A better view is that the outcome in Williams [No 1] is not inconsistent with section 116.

The religious test clause states that "no religious test shall be required as a qualification for any office or public trust under the Commonwealth'. Under the NSCP, in order to qualify as a 'school chaplain', a person was required to be recognised 'through formal ordination, commissioning, recognised qualifications or endorsement by a recognised or accepted religious institution or a state/territory government approved chaplaincy service'. ${ }^{160}$ That is, while it may be expected that most chaplains would be drawn from religious organisations, which was in fact the case, ${ }^{161}$ there was no requirement for chaplains to believe or disclaim certain religious doctrines, take any oath of office or adhere to any religious organisation. ${ }^{162}$ Recognition as a chaplain was not restricted to religious institutions.

Thus, it is difficult to see how this infringes the religious test clause; the guidelines could only be considered to breach this clause by significantly inflating the concept of 'religious test'. Nor is it easy to see how reading section 116 through the lens of intolerance materially changes this analysis. Rather, it is religiously tolerant to allow a diversity of religious and non-religious options for the provision of chaplaincy services. It would be intolerant to exclude religious chaplains or chaplains of particular religions. This conclusion is strengthened when pluralist elements are considered - it enables a beneficial interaction between the Commonwealth and religion without privileging any particular religion. Beck's attempt to remove religion from the government to the maximum extent possible through the lens of intolerance is not a convincing one.

157 See Beck, 'Establishment Clause' (n 67).

158 See Beck, Religious Freedom and the Australian Constitution (n 3) 161.

159 Ibid 165.

160 Williams [No 1] (2012) 248 CLR 156, 222 [107] (Gummow and Bell JJ).

161 Beck, 'Establishment Clause' (n 67) 233.

162 See Luke Beck, 'The Constitutional Prohibition on Religious Tests' (2011) 35(2) Melbourne University Law Review 323, 339. 


\section{CONCLUSION}

In this article, we have critiqued Luke Beck's 'safeguard against religious intolerance theory' of section 116 on the basis that it, among other things, rests on significant misunderstandings of the historical context of the recognition debate and the insertion of section 116 into the Constitution.

Thus far, the High Court has not engaged in any detailed analysis of the Convention Debates in interpreting section 116. This article forms a robust foundation for future scholarship on the doctrinal interpretation of section 116 so that the High Court may have a better informed historical understanding of the provision to aid their jurisprudence. Though we express no view in regard to Beck's claim that the historical context is necessary to understand section 116 properly, ${ }^{163}$ and are not providing a normative argument about the importance of history or claiming that history is determinative for constitutional interpretation, ${ }^{164}$ we note that a more accurate understanding of the history of constitutional provisions may have implications for their interpretation.

In line with other accounts of section 116, our arguments would tend to support a broader reading of the free exercise clause, which has never been employed to invalidate a Commonwealth law; however, contrary to other views which would propose a broader reading of the establishment and religious observances clauses, ${ }^{165}$ our arguments would tend to suggest a narrow reading of the establishment, religious observances and religious test clauses, in line with their current interpretation. However, it is beyond the scope of this article to fully spell out the implications for constitutional interpretation.

163 Beck, Religious Freedom and the Australian Constitution (n 3) 127.

164 But see, eg, Nicholas Aroney, 'The Justification of Judicial Review: Text, Structure, History and Principle' in Rosalind Dixon (ed), Australian Constitutional Values (Hart, 2018) 41, for concise and principled arguments supporting the importance of historical context for interpretation.

165 See, eg, Beck, 'Establishment Clause' (n 67); Beck, 'Dead DOGS?' (n 67). 